\title{
Somogy megye erdeicsótányai (Blattodea: Ectobiidae)
}

\author{
SZIRÁKI GYÖRGY
}

SzIRÁKI GY:: The native cockroaches of Somogy county (Blattodea: Ectobiidae)

Abstract: Three native cockroach species found hitherto in Somogy county are listed.

\section{Bevezetés}

A Magyarországról kimutatott 7 erdeicsótány közül Somogy megye különbözố területeirôl eddig 3 faj került elő. Ezek az alábbiak:

\section{A területról ismert fajok}

Ectobius silvestris (Poda, 1761)

Ectobius lucidus (Hagenbach, 1822)

Ectobius erythronotus nigricans Ramme, 1923.

Természetvédelmi szempontból közülük az Ectobius lucidus érdemel említést, amely a Kárpát-medencében csak néhány helyrôl került elő. Ezek között szerepel a Baláta-tó (VIDLICKA és SzIRÁKI 1997).

\section{Irodalom}

VidlickA, L. et SzIRÁKI, Gy. 1997: The native cockroaches (Blattaria) in the Carpathian Basin. Folia ent. hung. 58: 187-220.

ISSN 1587-1908 (Print); ISSN 2062-9990 (Online) 


\title{
The native cockroaches of Somogy county
}

\section{(Blattodea: Ectobiidae)}

\section{GYÖRGY SZIRÁKI}

Hitherto three of the seven Ectobiidae species of Hungary are known from Somogy county. One of them (Ectobius lucidus) is extremely rare in the Carpathian Basin and absent east of our country.

\author{
Author's address: \\ Dr. György SzIRÁKI \\ Hungarian Natural History Museum \\ H-1088 Budapest \\ Baross u. 13. \\ HUNGARY
}

